\title{
Dynamic Spin-Controlled Enantioselective Catalytic Chiral Reactions
}

Tzuriel S. Metzger ${ }^{1}$, Reema Siam ${ }^{2}$, Yuval Kolodny ${ }^{1}$, Naama Goren ${ }^{1}$, Nir Sukenik ${ }^{1}$, Shira Yochelis ${ }^{1}$, Raed Abu-Reziq ${ }^{2}$, David Avnir ${ }^{2}$ and Yossi Paltiel ${ }^{* 1}$

Center for Nanoscience and Nanotechnology, ${ }^{1}$ Department of Applied Physics and

${ }^{2}$ Institute of Chemistry, The Hebrew University, Jerusalem 9190401, Israel

\section{Supporting Information}

1. Further characterization of the reactions products

Figure S1: A. Chiral-HPLC separation of the commercial racemic sulfoxide products under

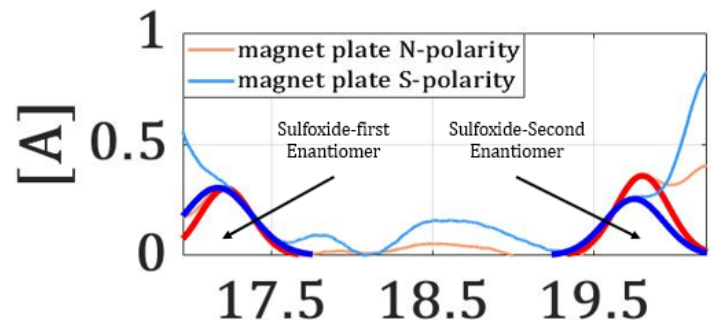

$\min$

\begin{tabular}{|c|c|c|c|c|}
\hline & $\begin{array}{l}\text { magnet plate } \\
\mathrm{N} \text {-polarity }\end{array}$ & $\begin{array}{l}\text { magnet plate } \\
\text { S-polarity }\end{array}$ & $\begin{array}{l}\text { magnet plate } \\
\text { in plane - } \\
\text { polarity }\end{array}$ & $\begin{array}{l}\text { Commercial } \\
\text { Products }\end{array}$ \\
\hline $\begin{array}{l}\text { first } \\
\text { Enantiomer } \\
\% \text { molar } \\
\text { fraction }\end{array}$ & $\begin{array}{c}45.75 \pm \\
0.85\end{array}$ & $\begin{array}{c}57.65 \pm \\
0.25\end{array}$ & $\begin{array}{c}50.48 \pm \\
0.30\end{array}$ & $\begin{array}{c}50.04 \pm \\
0.29\end{array}$ \\
\hline $\begin{array}{l}\text { second } \\
\text { Enantiomer } \\
\% \text { molar } \\
\text { fraction }\end{array}$ & $\begin{array}{r}54.25 \\
\pm 0.85\end{array}$ & $\begin{array}{l}42.35 \\
\pm 0.25\end{array}$ & $\begin{array}{l}49.52 \\
\pm 0.30\end{array}$ & $\begin{array}{r}49.96 \\
\pm 0.29\end{array}$ \\
\hline
\end{tabular}

$\stackrel{\text { A }}{\text { different magnetization directions at the reaction cell. The chromatogram areas were calculated }}$ from Gaussian fitting B (sulfone is a by-product). A table summarizing the enantiomeric \% molar fraction of the different experiments.

Figure S2: Reaction without a magnetic field. A. HPLC of the sulfoxide products with in-
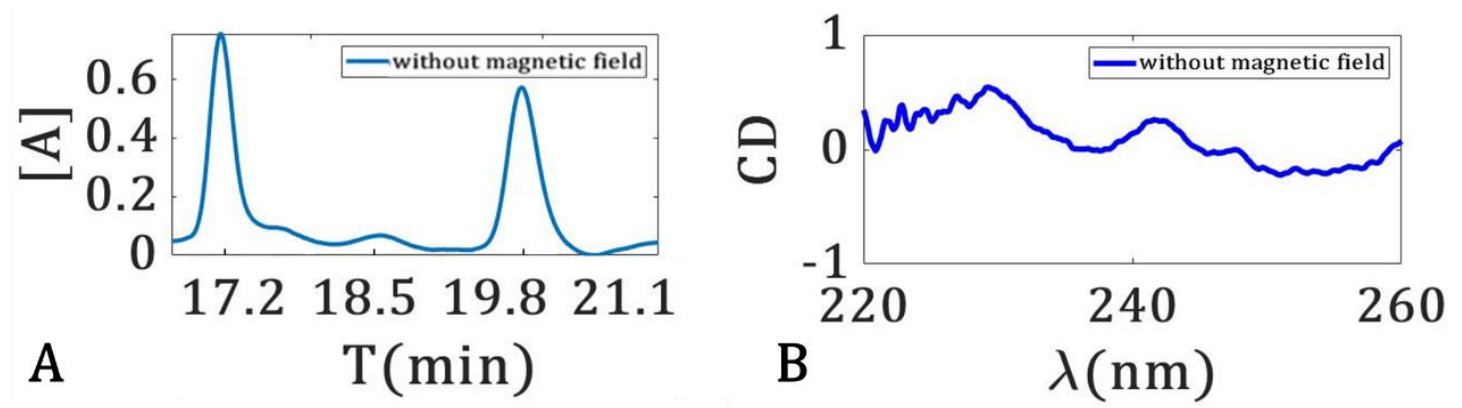

plane spins. The ee here is $\sim 1 \%$. B. CD spectrum of the product racemate, where no significant signal is observed above the noise level. 


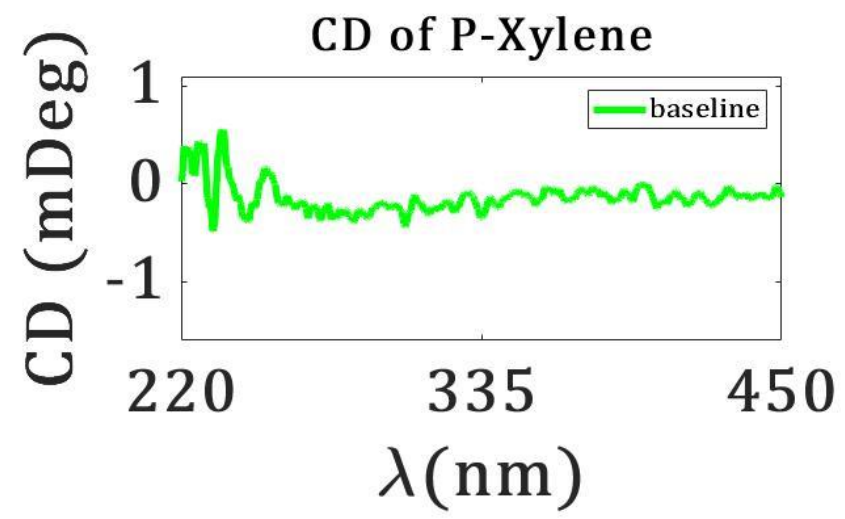

Figure S3: The CD spectrum of xylene, as baseline for the Diels-Alder reaction.

\section{Magnetic characterizations of the catalyst substrate}

Figure S4: SQUID characterization. A. Si | $12 \mathrm{Cr}|100 \mathrm{Au}| 20 \mathrm{Ni} \mid 10 \mathrm{Au}$ substrate,
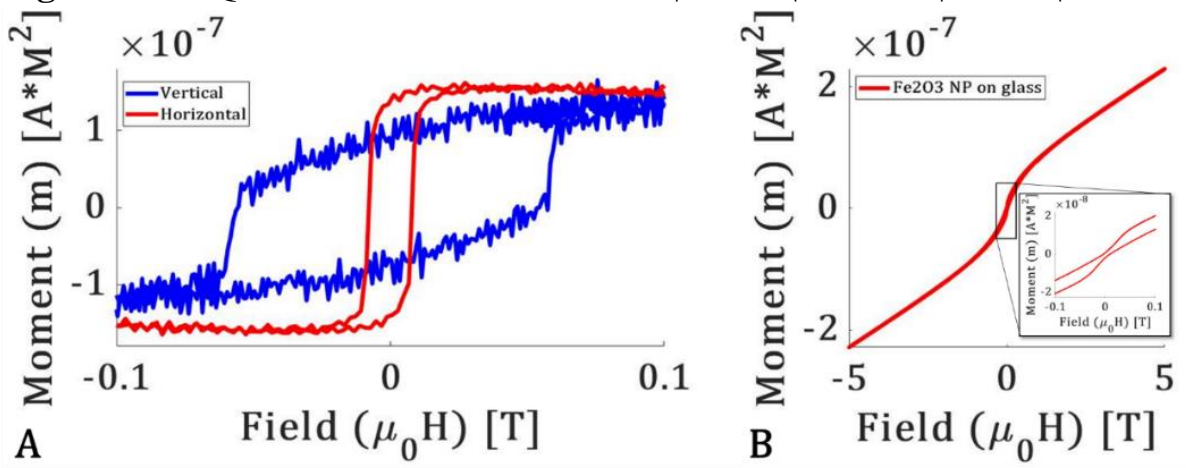

units in nm denoting for the thickness. The easy axis is in plane, while $0.5 \mathrm{~T}$ magnet can align the spins in the hard axis. B. $\mathrm{Fe}_{2} \mathrm{O}_{3} 102 \mathrm{~nm}$ NPs magnetic measurement. The particles demonstrate superparamagnetic character.

\section{$\underline{\text { 3. Materials and Methods }}$}

Materials: Acetaldehyde (\#SHBL3064, Sigma Aldrich), acetonitrile (\#1905201868, J. T. Baker), (aminomethyl)phosphonic acid (\#MFCD00008105, Sigma Aldrich), dichloromethane (\#STBJ6155, Sigma Aldrich), 2,3-dimethyl-1,3-butadiene (\#BCBZ9229, Sigma Aldrich), Ferric oxide particles (\#MKCD6115, Sigma Aldrich), hydrogen peroxide (\#SZBF0420V, Sigma Aldrich), anhydrous $\mathrm{MgSO}_{4}$ (\#7487-88-9, J. T. Baker), sodium sulfite (\#MKCL3609, Sigma Aldrich), thioanisole (\#STBH5431, Sigma Aldrich), xylene (\#STBH6700, Sigma Aldrich).

Equipment and HPLC: CD spectra are collected by JASCO J-810-150-S spectropolarimeter. Each spectrum presented is an average over five scanning runs. FTIR spectra are collected by Perkin Elmer Spectrum 100 FT-IR spectrometer. Chiral HPLC analysis is done using a Chiralpak® OD-H column $(4.6 \mathrm{~mm}$ ID, $250 \mathrm{~mm} \mathrm{~L}$, 
Daicel Chiral Technologies (China) Co., Ltd.) on a Surviyor LC Pump Plus HPLC instrument (Thermo Scientific, USA). High Resolution Mass determination, separation, qualitative and quantitative analysis by liquid chromatography Mass spectroscopy LC(UV)MS/MS using Agilent 6520 QTOF analyzer. Absorption spectra are collected by Ultraspec 2000 , Biochrom.

Preparation for HPLC and condition: after the neutralization of the $\mathrm{H}_{2} \mathrm{O}_{2}$ excess, the reaction mixture is extracted with $20 \mathrm{~mL}$ dichloromethane. The organic layer is dried on anhydrous $\mathrm{MgSO}_{4}$ and concentrated to get the reaction mixture. Analysis of the reaction mixture with MS was carried out before and after neutralization the $\mathrm{H}_{2} \mathrm{O}_{2}$ excess, as after the extraction - without any significant change. After evaporation of the solvent, the resulting material was dissolved in $1 \mathrm{~mL}$ of isopropanol. The separation of the enantiomers was performed with Chiralpak ${ }^{\circledR}$ OD-H column, using mobile phase of $15 \%$ isopropanol and $85 \%$ heptane at $30{ }^{\circ} \mathrm{C}$ at flow of $0.5 \mathrm{~mL}$ per minute. A $5 \mu \mathrm{L}$ injection volume is applied unless otherwise stated (in the calibration curve). 